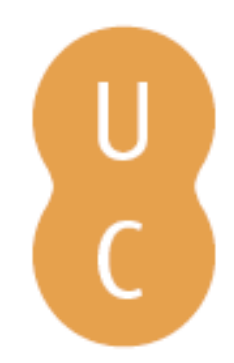

\title{
pกmpalina
}

\section{Fire effects on the physical environment in the WUI using FIRETEC}

Autor(es): $\quad$ Pimont, F.; Dupuy, J-L.; Linn, R. R.

Publicado por: Imprensa da Universidade de Coimbra

URL

persistente: URI:http://hdl.handle.net/10316.2/34310

DOI: $\quad$ DOI:http://dx.doi.org/10.14195/978-989-26-0884-6_83

Accessed : $\quad$ 26-Apr-2023 11:22:38

A navegação consulta e descarregamento dos títulos inseridos nas Bibliotecas Digitais UC Digitalis, UC Pombalina e UC Impactum, pressupõem a aceitação plena e sem reservas dos Termos e Condições de Uso destas Bibliotecas Digitais, disponíveis em https://digitalis.uc.pt/pt-pt/termos.

Conforme exposto nos referidos Termos e Condições de Uso, o descarregamento de títulos de acesso restrito requer uma licença válida de autorização devendo o utilizador aceder ao(s) documento(s) a partir de um endereço de IP da instituição detentora da supramencionada licença.

Ao utilizador é apenas permitido o descarregamento para uso pessoal, pelo que o emprego do(s) título(s) descarregado(s) para outro fim, designadamente comercial, carece de autorização do respetivo autor ou editor da obra.

Na medida em que todas as obras da UC Digitalis se encontram protegidas pelo Código do Direito de Autor e Direitos Conexos e demais legislação aplicável, toda a cópia, parcial ou total, deste documento, nos casos em que é legalmente admitida, deverá conter ou fazer-se acompanhar por este aviso. 


\section{ADVANCES IN}

Forest Fire

\section{RESEARCH}

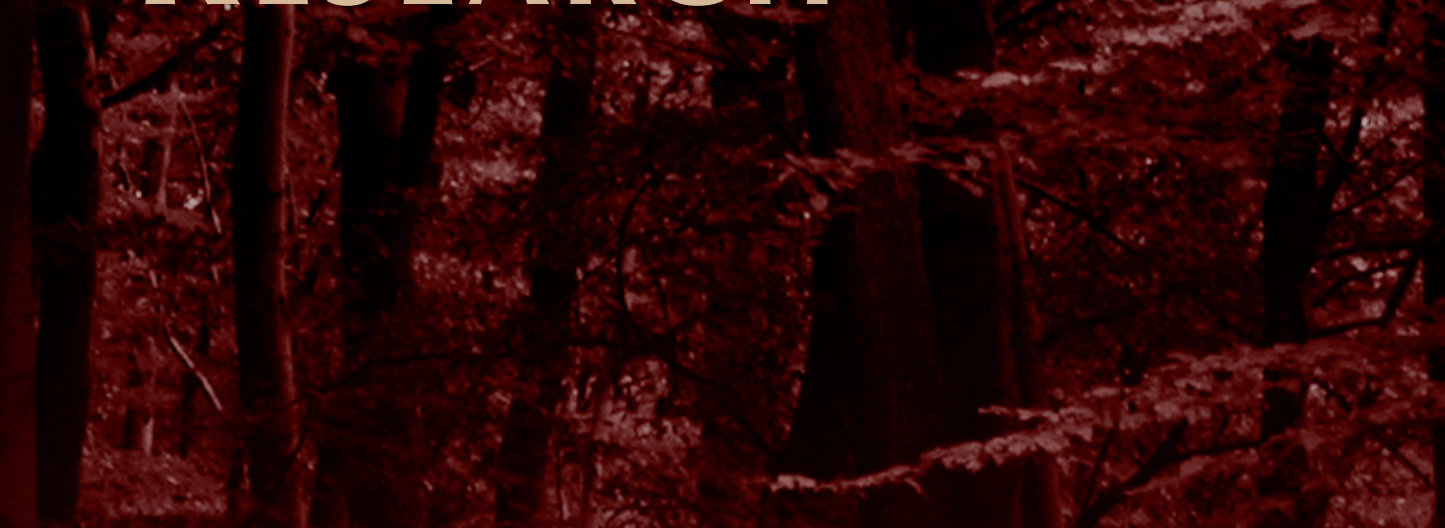

\section{DOMINGOS XAVIER VIEGAS}

\section{EDITOR}




\title{
Fire effects on the physical environment in the WUI using FIRETEC
}

\author{
F. Pimont ${ }^{\mathrm{a}}$, J-L. Dupuy ${ }^{\mathrm{a}}$, R.R. Linn ${ }^{\mathrm{b}}$ \\ ${ }^{a}$ INRA, UR 629, Site Agroparc F-84914 AVIGNON Cedex 9, pimont@avignon.inra.fr \\ ${ }^{b}$ LANL, EES, Los Alamos NM 87544, rrl@lanl.gov
}

\begin{abstract}
In France, the clearing distance between buildings and forest edge is $50 \mathrm{~m}$, to allow fire fighters to protect those buildings. Current building recommendations in the wildland-urban interface derive from fire-safety tests on building materials using heat exposures (duration and magnitude) that are expected to be different from those produced by wildfires. Beyond a few experimental data released after the International Crown Fire Modelling Experiment, there is a lack of characterisation of the physical environment of a building or human target within a cleared area, that receives hot gases and radiant fluxes from a crown fire. In the present study, we evaluate FIRETEC's ability to simulate heat fluxes based on some available experimental data and subsequently use it to characterize the radiant fluxes, gas temperatures and velocities around a human or building target.

Simulations have been performed in a mature Aleppo pine forest within a 600 by $400 \mathrm{~m}$ domain. The conditions of the fire spread were severe $\left(30^{\circ} \mathrm{C}\right.$, wind up to $50 \mathrm{~km} / \mathrm{h}$, slope until $\left.30 \%\right)$. Radiant fluxes and gas temperatures were computed for several distances between the forest tailing edge and a target that represents either a building or a fire fighter.

Peak radiant heat flux magnitudes decreased by about $80 \%$ when the target was at $50 \mathrm{~m}$ compared to a target at $10 \mathrm{~m}$. This is between 90 and $95 \%$ reduction o0f radiant flux reduction observed at $50 \mathrm{~m}$ compared to the forest edge. For the purpose of comparison with reference acceptable thresholds for both materials and fire fighters, the peak values of the average over one minute of the instantaneous radiant fluxes and gas temperatures were computed. These values support the notion that a clearing distance of $50 \mathrm{~m}$ is appropriate in the tested conditions for both thermal radiation and gas temperature, even if radiant fluxes remain high is the sloped case.

This study shows a new type of application for physics-based models such as FIRETEC. Simulations demonstrate the interest of clearing around buildings and can help provide recommendations about the appropriate clearing distance. It can also be used for building material specifications.
\end{abstract}

Keywords: WUI, clearing, radiant flux, gas temperature, building, FIRETEC

\section{Introduction}

In France, the clearing distance between buildings and forest edge is $50 \mathrm{~m}$. The aim of this recommendation is to limit fire effects on building, but also to offer safe conditions for fire fighters protecting the building. Current building recommendations in the wildland-urban interface have been derived from fire safety tests on building materials using heat exposures (duration and magnitude) that are of different ranges from those produced by wildfires. Beyond the experimental data released after the International Crown Fire Experiment (Cohen 2004), there is a lack of characterisation of the thermal exposure of a building within a cleared area receiving hot gases and radiant fluxes from a crown fire. Modeling radiatives fluxes is challenging because of its extreme sensitivity to, among other parameters, gas temperature due to the fourth-power dependence of temperature of the emissive power. An error of $20 \%$ on temperature induces an error of $100 \%$ on radiative flux. Most of the modelling approaches used up to now assume a value for gas temperature and a shape for the source (Ellis 2000, Billaud et al. 2011). In physics-based models such as FIRETEC (Linn \& Cunningham, 2005), the local values of gas and solid temperatures and absorption coefficients are computed in 3D by the model itself. These types of models resolve gas transport and combustion equations, coupling heat transfer, transport and combustion. Because of the physical basis of such a model, a satisfactory evaluation over some specific experimental data can give some confidence in the prediction within a slightly broader context. For instance, Linn et al. (2012) show some first results demonstrating a reasonable agreement 
between the model and the crown fire experiment, even if large uncertainties in wind conditions were complicating the validation process.

In the present study, we evaluate FIRETEC's ability to simulate radiant heat flux using data collected during the International Crown Fire Experiment (Cohen et al. 2004). We thus used the model to characterize the radiant fluxes, gas temperatures and velocities to a human or building target. For an evaluation of FIRETEC's predictions of gas temperature and velocities in front and above a fire, the interested reader can refer to Dupuy et al. (2014).

\section{Methods}

\subsection{Model evaluation: ability to simulate a radiant heat flux on a vertical target}

Following the work of Linn et al. (2012), fire behaviour was simulated on four different plots of the International Crown Fire Experiments. Plot 1, 4, 6 and 9 were selected because of the relatively uniform fire behaviour observed during the experiment (Taylor et al. 2004, see figure 4). Cohen et al. (2004) provided information concerning radiant heat fluxes to a target at 10, 20 and $30 \mathrm{~m}$ from the trailing edge: figure 6 shows the temporal variation in incident heat flux for Plot 4 and 9 and table 2 the peak total incident heat $\left(\mathrm{kW} \cdot \mathrm{m}^{-2}\right.$ ) for plot 1, 4, 6 and 9 (except at $10 \mathrm{~m}$ for plot 1 and $20 \mathrm{~m}$ for plot $6)$.

The experimental fuels were simulated using the Fuel Manager (Rigolot et al. 2010), that provides an explicit representation of each individual tree, based on ICFME data inventory (Alexander et al. 2004). Canopy load maps are plotted on Figure 1.
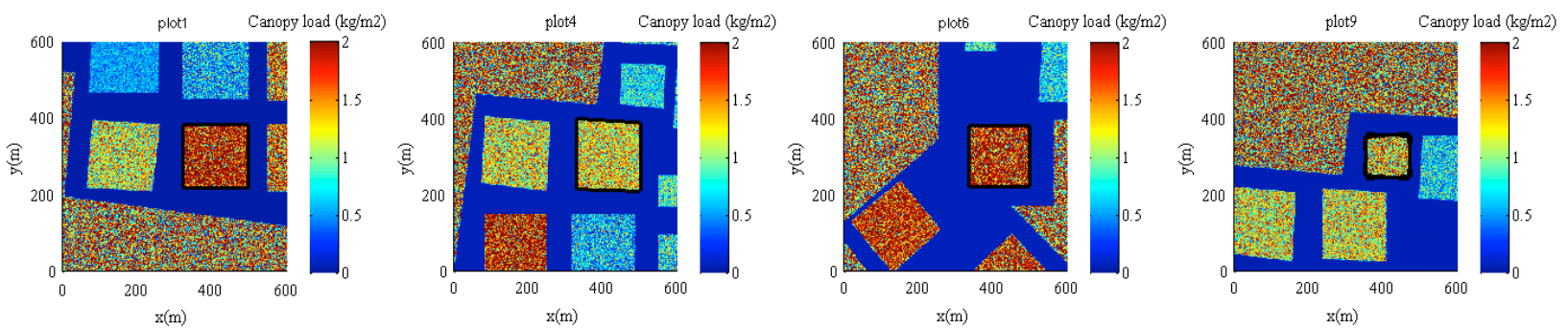

Figure 1. Canopy load maps for the four plots of the ICFME used for the model evaluation. The reference plot is circled in black. On these plots, the wind comes from the left side.

The ambient wind were precomputed using the large scale pressure gradient forcing described in Pimont et al. (2014) over homogeneous canopies and were used as boundary conditions for each fire run in order to match the order of magnitude of the reference value in the open (respectively $2.8 \mathrm{~m} / \mathrm{s}$, $4.1 \mathrm{~m} / \mathrm{s}, 4.8 \mathrm{~m} / \mathrm{s}, 6.9 \mathrm{~m} / \mathrm{s}$ at $10 \mathrm{~m}$ for plot 1, 4, 6 and 9). Fire was ignited using a "terratorch" procedure, similar to the one used by Linn et al. (2012) to reproduce the progressive linear ignition used during those experiments.

FIRETEC uses a Monte-Carlo approach to compute the radiative transfer from any computational voxel of gas and fuel to another one. More details can be found in Dupuy et al. (2011). To compute radiative flux toward a vertical target, the number of photons that crosses the vertical cell faces corresponding to target positions were counted. Another specificity of this application is that it required a good accuracy of radiant heat fluxes "far from the flame", whereas what really matters for fire propagation is a good accuracy of radiant heat fluxes "close to the flame". To reach a better accuracy on targets at up to $30 \mathrm{~m}$ from the flame, we increased the number of photons thrown by the Monte-Carlo code.

The simulated fires had spread rates of respectively $0.7,0.65,0.8$ and $1.06 \mathrm{~m} / \mathrm{s}$ for plot $1,4,6$ and 9 . The experimental spread rates were $0.6,0.74,0.6,1.16 \mathrm{~m} / \mathrm{s}$ for the same plots. It should be noticed that these experimental fires were performed in a wide range of wind conditions, temperature and fuel 
characteristics. Considering the uncertainties associated to wind field description in the experiment and the sensitivity of the model to wind fields (Linn et al. 2012), the agreement between experimental and modelled spread rates was found satisfactory.

Using data provided by Cohen et al. (2004), FIRETEC's radiant fluxes to targets were plotted against experimental data on Figure 2 for plot 4 and 9. For each distance to the trailing edge $(10,20$ and $30 \mathrm{~m})$, data was collected from FIRETEC simulations were at three different lateral positions (centered, $10 \mathrm{~m}$ right and $10 \mathrm{~m}$ left from the central axis parallel to wind direction) in order to illustrate the spatial variability of the simulated data. For plot 4, the agreement with the experiment was found to be satisfactory: the abrupt rise was very well captured by the model, as well as satisfactory values of peak. The decline occurs quicker in the model than in observations, which can be attributed to the fact that fuels thicker than $6 \mathrm{~mm}$ are not accounted for in the model and might play a significant role after the fire front has passed. Radiant heat flux peaks were underestimated on plot 9 by about $30 \%$. However, it should be noticed that the model rendered the fact that the peak was significantly higher in plot 9 than in plot 1, 4 and 6. Among the reasons that could help to understand the discrepancy, we noted that the modelled spread rate was underestimated $(1.06$ instead of $1.16 \mathrm{~m} / \mathrm{s})$ and Figure 3 illustrates that the modelled fire was more tilted and not as straight as the experimental fire. This might explain why the radiant heat flux was underestimated in this context.
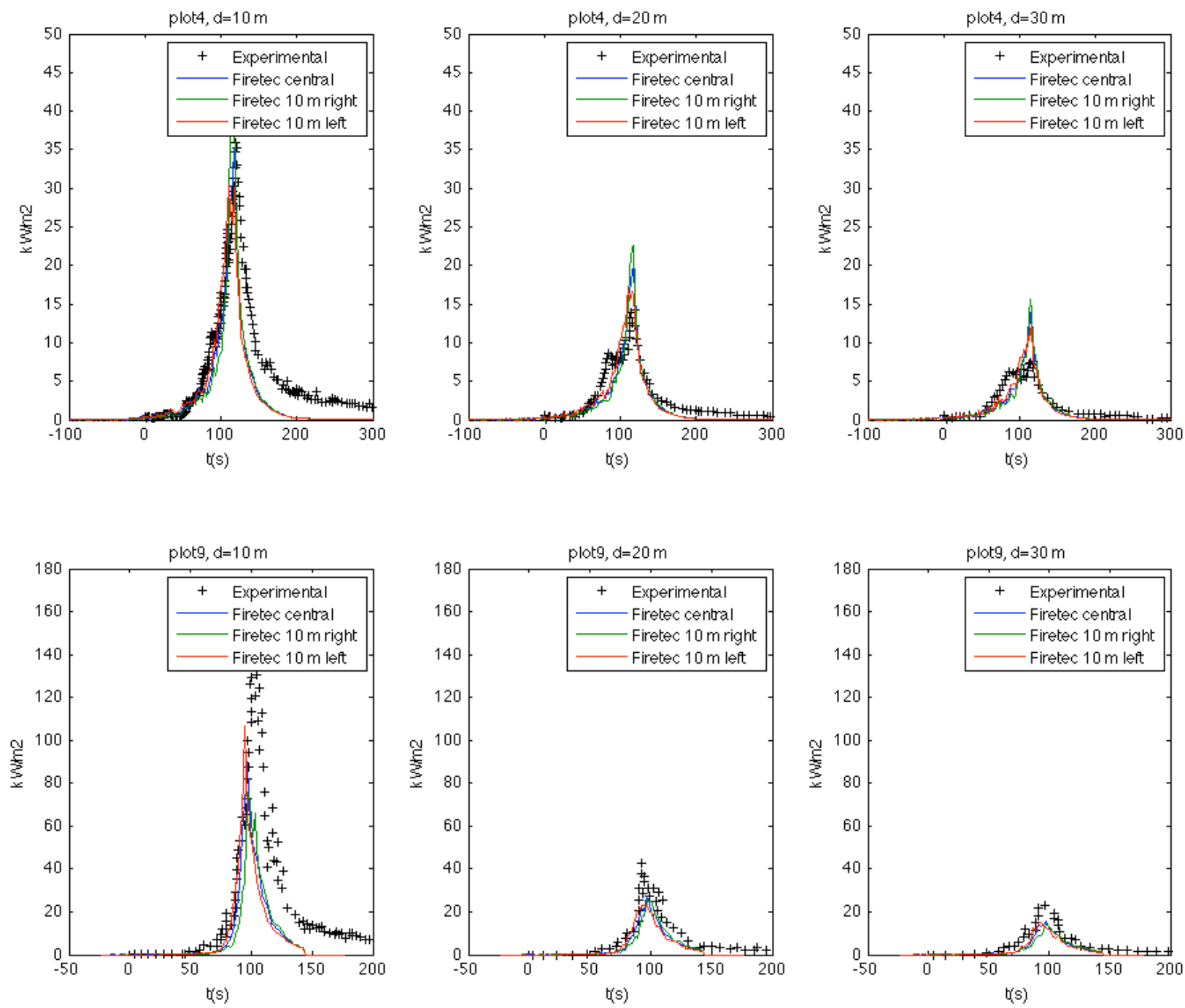

Figure 2. Simulated radiant heat flux at a target at $d=10,20$ and $30 \mathrm{~m}$ downwind of the trailing edge of plot 4 and 9. Experimental data were taken from Cohen et al. (2004) 

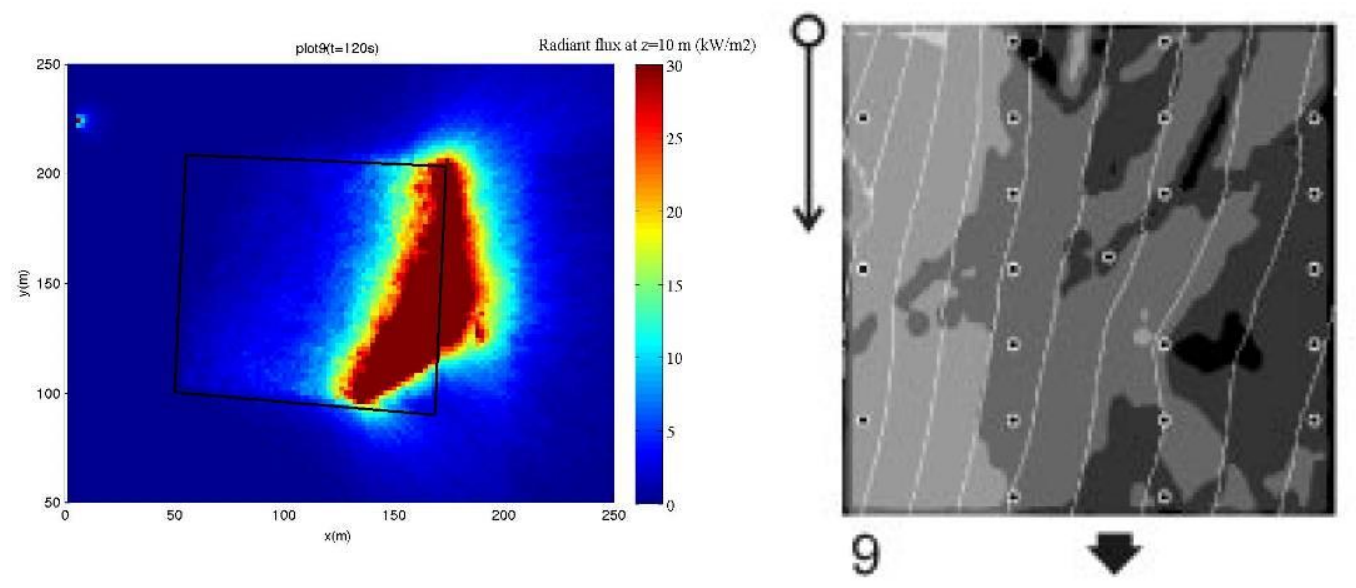

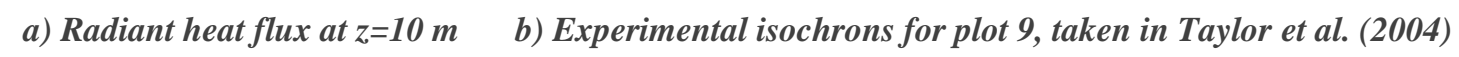

Figure 3. Simulated peak radiant heat flux at a target at $d=10,20$ and $30 \mathrm{~m}$ downwind for plot 1, 4, 6 and 9

Cohen et al. (2004) also provided radiant heat flux peak values for plot 1, 4, 6 and 9. Figure 4 represents the simulated peak values against the experimental ones (FIRETEC's center value was chosen here). A log scale was chosen because of the wide range of radiant fluxes among cases and distances. Again, the agreement was satisfactory.

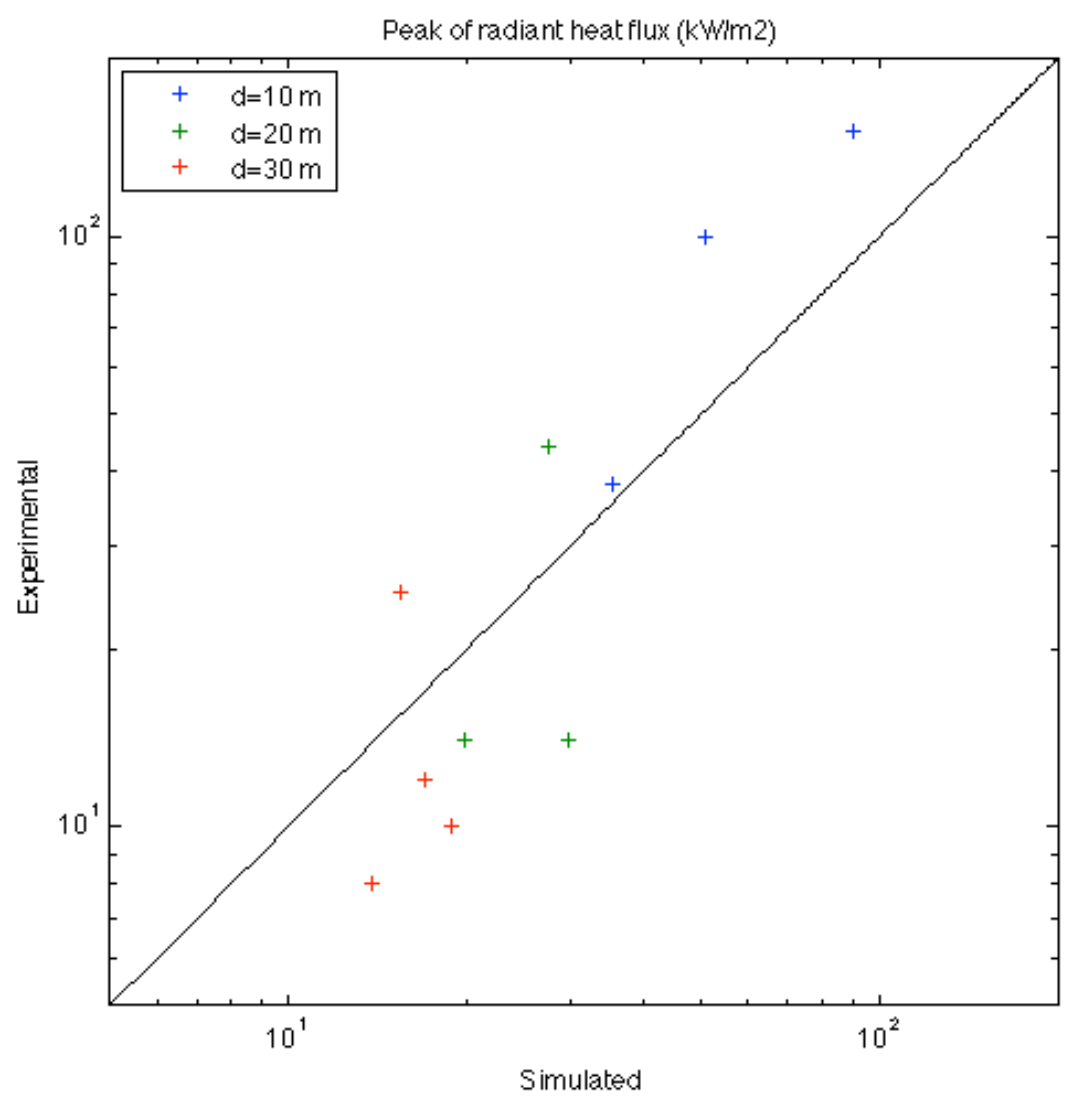

Figure 4. Simulated peak radiant heat flux at a target at $d=10,20$ and $30 \mathrm{~m}$ downwind for plot 1, 4, 6 and 9. NB: $d=10 \mathrm{~m}$ is missing for plot 1 and $d=20 \mathrm{~m}$ is missing for plot 6 


\subsection{Radiant fluxes in Aleppo pine stand}

Four simulations were carried in a mature Aleppo pine forest over a 600 by $400 \mathrm{~m}$ domain (Table 1, Figure 5). The forested area is a 40 year old Aleppo pine stand of medium fertility class (corresponding to a dominant height at 50 year old of $12 \mathrm{~m}$ ) with 1100 stems per ha. The understory is a mixed oak shrubland of 40 year old and has a cover fraction of $80 \%$. The fuel scene was simulated with the Fuel Manager (Rigolot et al. 2010) and can be seen on Figure 5. The simulated fuel scene has a pine/oak cover fraction of $88 \%$ and a fuel load of $1.35 \mathrm{~kg} / \mathrm{m} 2$, whereas the oak understorey has fuel load of $0.72 \mathrm{~kg} / \mathrm{m} 2$.

Two different options were tested in the cleared area (see Table 1). Run1 and run2 have some remaining Aleppo pines on the first $20 \mathrm{~m}$ of the cleared area, but those pines were thinned so that distances between tree crowns are everywhere greater than $3 \mathrm{~m}$. In the second scenario (run 3 and run4), all the pine trees and oaks were removed. We assumed that there was no ground fuel in the cleared area. Even if this assumption might be found restrictive in such a study, the mesh size of FIRETEC $(2 \mathrm{~m})$ is not really appropriate to deal with propagation of a fire in heterogeneous resprouts or patchy fuel at a scale much smaller than grid size. For that reason, this study focuses on the fire effects of the main fire front, spreading from the untreated region (and through thinned trees in the first $20 \mathrm{~m}$ of the cleared area when pine trees were only thinned at $3 \mathrm{~m}$ between crowns). The reader must be aware that the effect of the fuel recovery in the cleared area is not accounted for. The consequences of this assumption will be discussed in section 4 .

The conditions of the fire spread were severe: the air temperature was $30{ }^{\circ} \mathrm{C}$, with a wind speed of 50 $\mathrm{km} / \mathrm{h}$ (at $10 \mathrm{~m}$ in the open that is upwind to the forest), the slope can reach $30 \%$ and the fuel moistures were dry (100\% for Aleppo pine needles, $70 \%$ for live understorey fuel and dead fuel moisture of 10 $\%$ ). In addition, the cleared area is reached frontally by a crown fire with a wide firefront (about $100 \mathrm{~m}$, when if reaches the cleared area).

Table 1. Description of the four Aleppo pine simulations

\begin{tabular}{|l|c|c|c|}
\hline & Wind at $10 \mathrm{~m}$ in the open & Slope (\%) & $\begin{array}{c}\text { Presence of trees in the first } 20 \mathrm{~m} \text { of the } \\
\text { cleared area }\end{array}$ \\
\hline Run1 & $50 \mathrm{~km} / \mathrm{h}$ & $0 \%$ & Yes \\
\hline Run2 & $50 \mathrm{~km} / \mathrm{h}$ & $30 \%$ & Yes \\
\hline Run3 & $50 \mathrm{~km} / \mathrm{h}$ & $0 \%$ & No \\
\hline Run4 & $50 \mathrm{~km} / \mathrm{h}$ & $30 \%$ & No \\
\hline
\end{tabular}

The fluxes and gas temperatures were computed at several distances $(\mathrm{d}=10,30$ and $50 \mathrm{~m})$ downwind of the full-forest trailing edge including a $10 \mathrm{~m}$ height target that represents a building (Figure 5). To account for spatial variability, ten different virtual targets were used at each of the three reference distances. As in the evaluation procedure described in section 2.1, the number of photons used in the MonteCarlo scheme was increased to increase long distance accuracy. It should be noticed that the target is virtual here, so that no computation of the flow motion around the building or fire fighter is done, which might affect the gas temperatures, but not the radiant fluxes. 


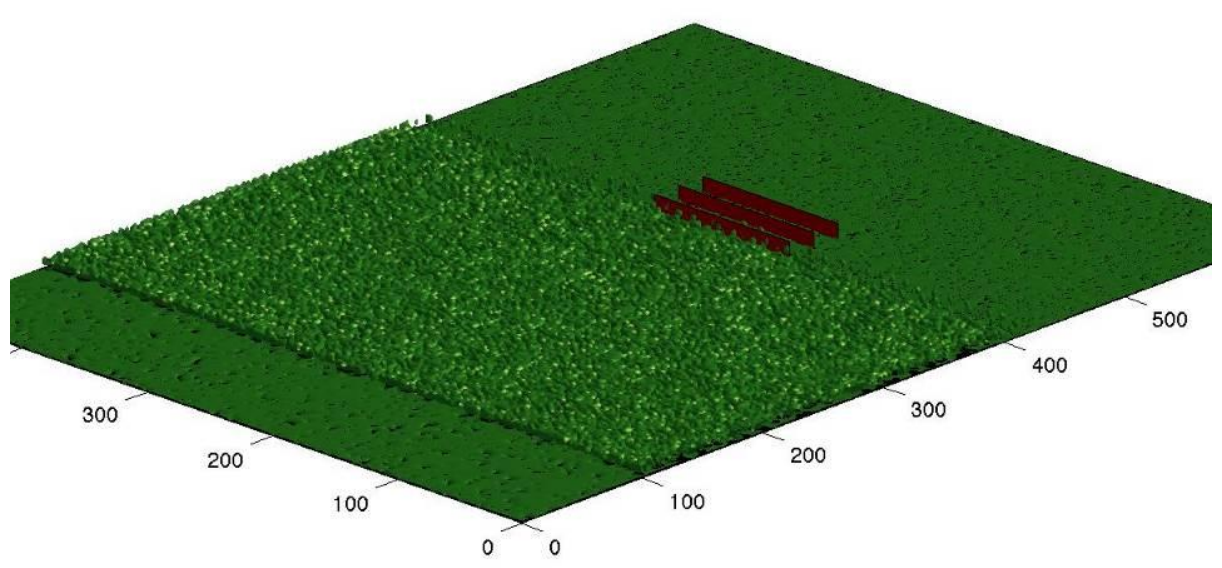

Figure 5. Schematic view of the numerical experiment in the no-slope scenario with tree thinning on the first $20 \mathrm{~m}$ of the cleaned area. The three red planes represent target location at respectively 10,30 and $50 \mathrm{~m}$ from the forest edge.

In addition to the instantaneous radiant fluxes and temperatures similar to Figure 2, the peaks of 1 minaveraged radiant fluxes and temperatures where computed at 30 different locations in order to compare them to some known thresholds. The 30 different locations (10 for each distance $d=10,30$ and $50 \mathrm{~m}$ ) were then used to compute a maximum and mean value of peak time-averaged quantities over space.

\section{Results}

\subsection{Fire behaviour}

The fire behaviour computed by FIRETEC in the scenario described above was always an active crown fire (Figure 6), with computed spread rates of $1.05 \mathrm{~m} / \mathrm{s}$ for the no slope scenarios (run 1 and run3) and of $1.30 \mathrm{~m} / \mathrm{s}$ for the $30 \%$ slope scenarios (run2 and run4). For the no slope scenarios, the fire intensities reached $27000 \mathrm{~kW} / \mathrm{m}$ at the head of the fire with a residence time of about $70 \mathrm{~s}$. For the $30 \%$ slope scenarios, the head-fire intensity reached $36500 \mathrm{~kW} / \mathrm{m}$ with a residence time of about $100 \mathrm{~s}$. Even if the fuel types are different, those values can be compared to the most documented crown fire experiments to date (ICFME, see above, Taylor et al. 2004), in which spread rates of more than 1.1 $\mathrm{m} / \mathrm{s}$ were experimented with wind of less than $25 \mathrm{~km} / \mathrm{h}$ on similar fire fronts without slope. Residence times between 63 and $94 \mathrm{~s}$ were reported at the ground and close to $30 \mathrm{~s}$ in the canopy. 


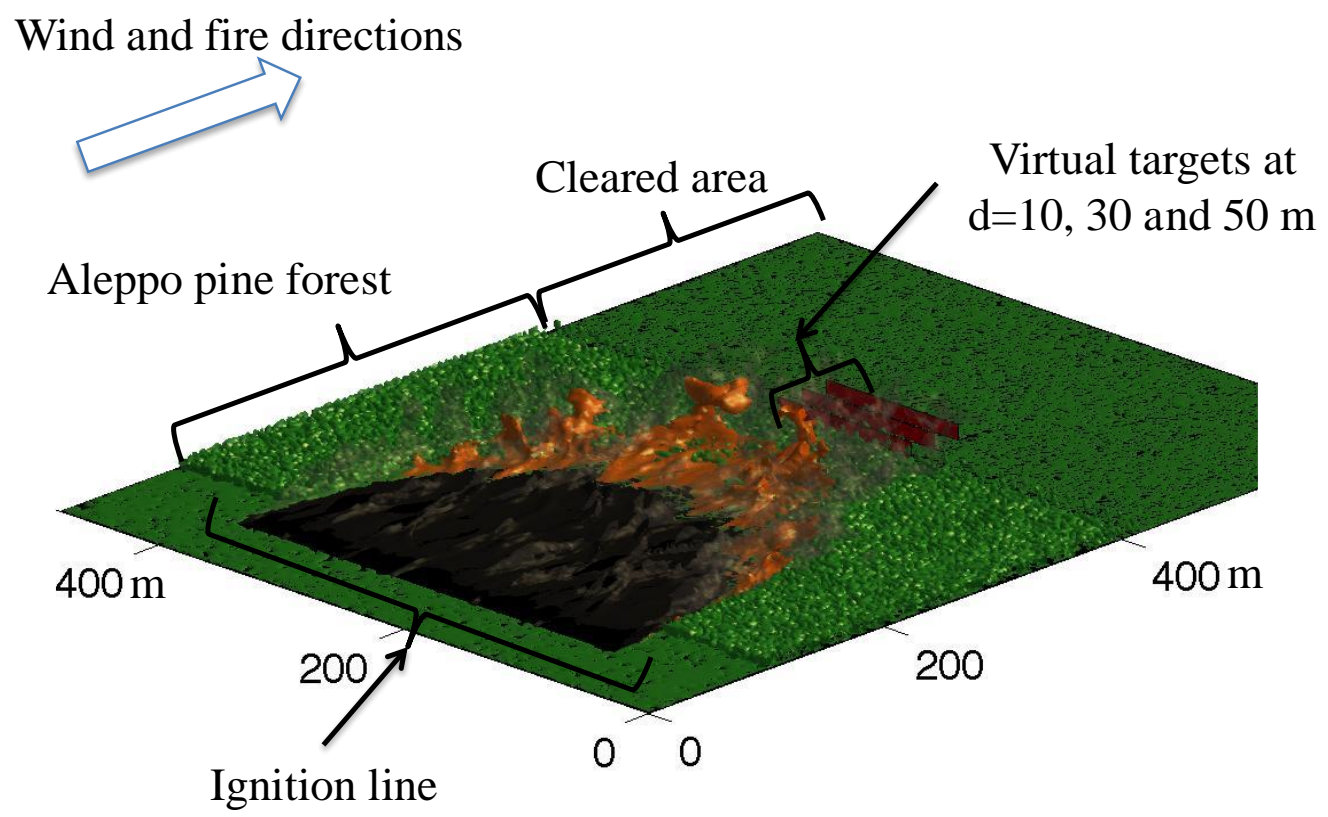

Figure 6. Fire propagation on the forest zone in the no-slope case

\subsection{Instantaneous and time-averaged radiant heat fluxes}

Figure 7 shows how the radiant heat flux decreased of approximately $80 \%$ when the target was $50 \mathrm{~m}$ from the forest compared to a target at $10 \mathrm{~m}$. This is up to 90 to $95 \%$ of radiant flux reduction at $50 \mathrm{~m}$ compared to the values at the forest edge, that reach $200 \mathrm{~kW} / \mathrm{m}^{2}$. In Table 2 , the mean and maximum (in brackets) value corresponds to spatial mean and max among virtual targets of the peak values of time-averaged fluxes. Mean peak average fluxes at $50 \mathrm{~m}$ were about $5 \mathrm{~kW} / \mathrm{m}$ for the no slope cases and of $8 \mathrm{~kW} / \mathrm{m}$ for the $30 \%$ slope cases. The decrease associated with distance from forest edge was slightly lower for time-averaged quantities than for instantaneous quantities, with a reduction about of about $75 \%$ between 10 and $50 \mathrm{~m}$ data. The presence of thinned trees in the first $20 \mathrm{~m}$ of the cleared area (with distance between crowns of $3 \mathrm{~m}$ in run 1 and run3) generally induced a small decrease of radiant heat fluxes for distances higher than $10 \mathrm{~m}$ (about $4 \%$ ), suggesting that those trees are not strong shelter for the targets. However, at $10 \mathrm{~m}$ the ignition of those trees can result in a $10 \%$ increase of heat flux.

The standard deviation of the peak of 1 min-averaged fluxes among the targets at various crosswind positions was limited (not shown), suggesting that spatial variability was limited with a wide and homogeneous fire front. The maximum of the peak averaged flux was about $10 \%$ higher than the mean value. It should be noticed that the maximum value for run 4 at $10 \mathrm{~m}$ was $20 \%$ higher than the mean value, illustrating that variability could be higher close to the forest edge with slope. 


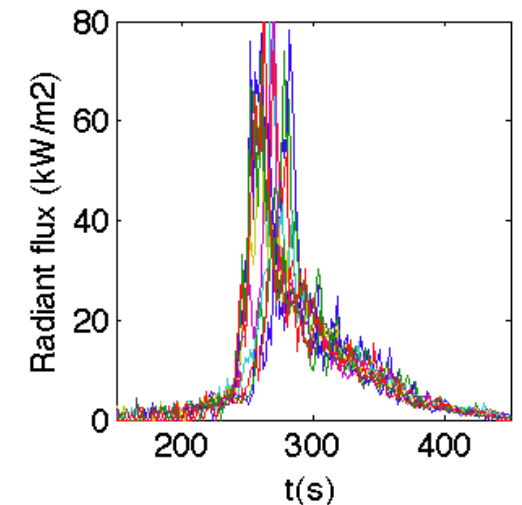

a) $d=10 \mathrm{~m}$

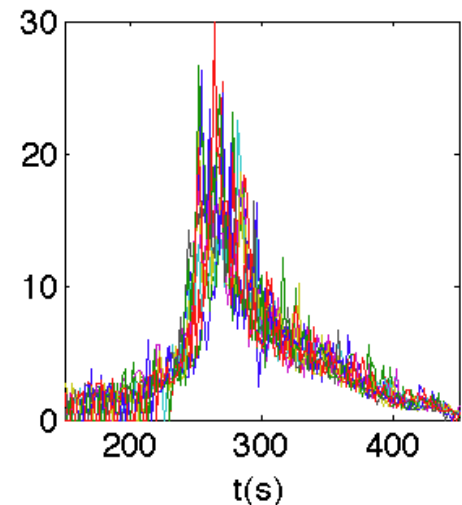

b) $d=30 m$

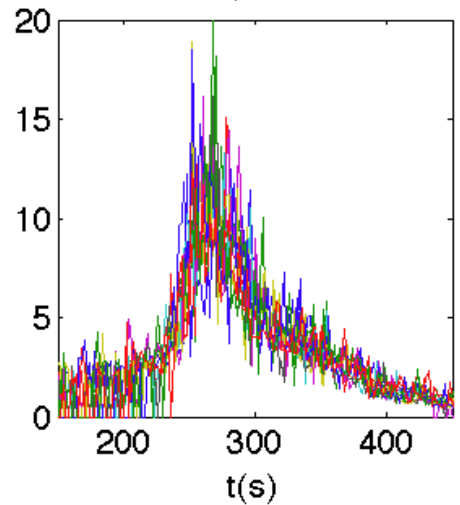

c) $d=50 \mathrm{~m}$

Figure 7. Radiant fluxes to targets at 10, 30 and $50 \mathrm{~m}$ from the forest edge in the $30 \%$ slope case

Table 2. Spatial mean (max) as a function of distance d of the peak of 1 min-averaged radiant heat flux (kW/m2)

\begin{tabular}{|l|c|c|c|}
\hline & $\mathrm{d}=10 \mathrm{~m}$ & $\mathrm{~d}=30 \mathrm{~m}$ & $\mathrm{~d}=50 \mathrm{~m}$ \\
\hline Run1 (no slope, trees) & $24.6(27.8)$ & $8.6(9.2)$ & $5.5(5.9)$ \\
\hline Run2 (30\% slope, trees) & $31.1(34.6)$ & $12.2(13.2)$ & $8.4(9.1)$ \\
\hline Run3 (no slope, no trees) & $22.0(25.8)$ & $8.3(8.8)$ & $5.4(5.9)$ \\
\hline Run4 (30\% slope, trees) & $30.0(38.8)$ & $11.8(13.1)$ & $8.0(8.9)$ \\
\hline
\end{tabular}

\subsection{Instantaneous and time-averaged temperatures}

Figure 8 illustrates how the distance to the edge affects gas temperatures on the $10 \mathrm{~m}$ height target. The instantaneous values were much smaller than inside the forest, where they could reach 1000$1100{ }^{\circ} \mathrm{C}$. Peak duration was always shorter than 2 minutes. Due to the large fluctuations associated with instantaneous data in the plume (Dupuy et al. 2014), the peak values of the 1 min-average were computed for each of the 30 targets, so that mean and max peak average temperature were computed in Table 3. The peak 1 min-averaged temperature decreased significantly with clearing distance to reach values significantly lower than $90^{\circ} \mathrm{C}$, with can be considered as a reasonable threshold for fire fighters. One interesting result is that peak 1 min-averaged temperatures could be $10 \%$ lower in the slope cases, than in the flat cases at $50 \mathrm{~m}$, whereas there were very significantly higher at $10 \mathrm{~m}(+15-$ $25 \%)$. The stronger plume associated with the more intense fire in the sloped cases could result in their plumes being less tilted from vertical, with lower temperatures at long distances $(50 \mathrm{~m})$, whereas they are higher at short distances $(10 \mathrm{~m})$ close to the more intense plume and due to the slope effect. Lower gas temperatures in front of higher intensity fires have already been observed by Pimont et al. (2011), in the context of fuel treatment. 


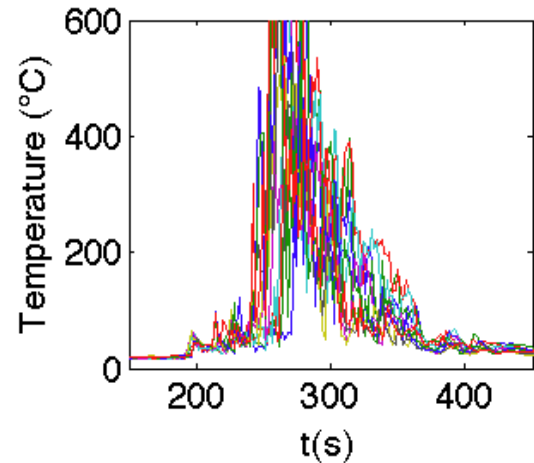

a) $d=10 m$

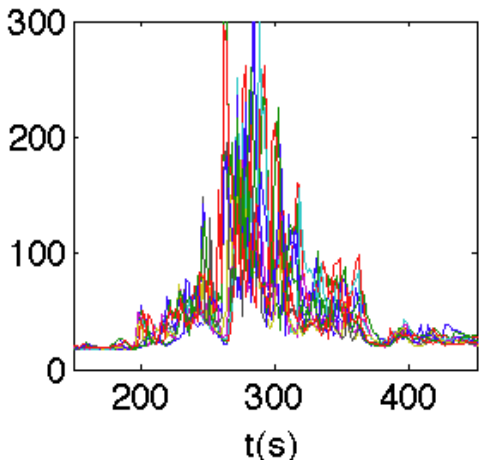

b) $d=30 \mathrm{~m}$

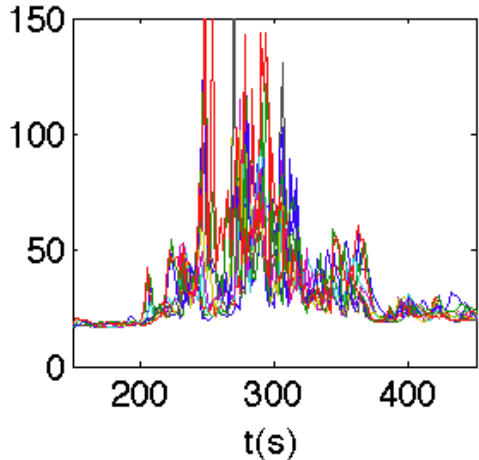

c) $d=50 \mathrm{~m}$

Figure 8. Gas temperature fluxes around targets at 10, 30 and $50 \mathrm{~m}$ from the forest edge in the 30\% slope case

Table 3. Spatial mean (max) as a function of distance $d$ of the peak of 1 min-averaged temperature $\left({ }^{\circ} \mathrm{C}\right)$

\begin{tabular}{|l|c|c|c|}
\hline & $\mathrm{d}=10 \mathrm{~m}$ & $\mathrm{~d}=30 \mathrm{~m}$ & $\mathrm{~d}=50 \mathrm{~m}$ \\
\hline Run1 (no slope, trees) & $287(323)$ & $105(111)$ & $71(78)$ \\
\hline Run2 (30\% slope, trees) & $329(404)$ & $110(130)$ & $59(70)$ \\
\hline Run3 (no slope, no trees) & $280(336)$ & $108(120)$ & $68(75)$ \\
\hline Run4 (30\% slope, trees) & $345(422)$ & $113(143)$ & $63(70)$ \\
\hline
\end{tabular}

\section{Discussion and conclusion}

The evaluation of the fire behaviour and radiant flux predictions against the ICFME, as well as the results presented by Dupuy et al. (2014) suggest that FIRETEC is able to reproduce the main trends associated with physical variables with the right orders of magnitude. This evaluation is limited for the moment, but we can expect to evaluate the model in a wider range of conditions in the future, thanks to new field experiment campaigns. However, no model deficiency was identified in these first comparisons, so that the model can be used with some degree of confidence to contribute to the evaluation of the effects of various clearing distance or to investigate how wind, slope and fuel treatment can affect radiant heat fluxes and gas temperatures. Certainly such modelling results should be used in a complementary fashion with additional more detailed experiments.

The results of the present study confirm that a significant clearing distance around houses can have a huge impact to enable the intervention of fire fighters. For instance, the clearing distance of $50 \mathrm{~m}$ induced a decrease of 90 to $95 \%$ of the peak radiant flux, as well as a reduction of $80 \%$ of the peak 1 min-averaged heat flux. The peak 1 min-averaged temperatures below $90^{\circ} \mathrm{C}$. It should be noticed that with the $30 \%$ slope and severe conditions, a clearing distance of $30 \mathrm{~m}$ was not sufficient to allow defensibility, mainly because of the radiant fluxes.

Concerning building protection, the heat fluxes show that a clearing distance of $10 \mathrm{~m}$ is clearly insufficient to avoid direct ignition of woody materials, whereas a clearing distance of $50 \mathrm{~m}$ would be enough to limit the risk of direct ignition. In the present study, the cleared area was assumed to contain no burnable fuel, with the exception of low cover of pines trees in the first $20 \mathrm{~m}$ of the cleared area in run 1 and run2. It should be noticed that even when the cleared area has been cleared very recently, some fuels and remaining litter can spread the fire to the building. And because the treatment are not done every year, the law allows the owner to have a phytovolume that can reach $5000 \mathrm{~m} 3 / \mathrm{ha}$, which can represent a fuel load 0.3 to $0.5 \mathrm{~kg} / \mathrm{m}^{2}$. FIRETEC is not the most appropriate model to deal with fire spread in area that has been cleared very recently, with sparse fuel or duff that will carry low intensity fire. The presence of fire fighters or house inhabitants is in general sufficient to avoid house ignition due to these low intensity fires associated with sparse fuels. However, the scenario of a 
significant accumulation of phytovolume $\left(5000 \mathrm{~m}^{3} / \mathrm{ha}\right)$ would worth to be simulating: the model is appropriate to do it, if the fuel is relatively homogeneous, as in a low garrigue and the presence of those fuel is likely to significantly modify the heat fluxes and temperatures. Such simulations will be done in the future and could be used to advise prescriptions concerning the fuel accumulation allowed on cleared area around houses.

This study shows a new type of application for physics-based models such as FIRETEC. Simulations demonstrate the value of clearing around house and can help provide recommendations about the appropriate clearing distance. It can also be used for building material specifications such as those released by the French Scientific and Technical Building Center (CSTB).

\section{References}

Alexander ME, Stefner CN, Mason JA, Stocks BJ, Hartley GR, Maffey ME, Wotton BM, Taylor SW, Lavoie N, Dalrymple GN. 2004. Characterizing the Jack Pine - Black spruce Fuel Complex of the International Crown Fire Modelling Experiment (ICFME). Information Report NOR-X-393. Canadian Forest Service Northern Forestry Centre. 49 pp.

Billaud Y, Kaiss A, Consalvi JL, Porterie B. 2011. Monte Carlo estimation of thermal radiation from wildfire. International Journal of Thermal Sciences 50, 2-11.

Cohen JD. 2004. Relating flame radiation to home ignition using modeling and experimental crown fires. Canadian Journal of Forest Research 34, 1616-1626. doi:10.1139/X04-049

Dupuy JL, Pimont F, Linn RR, Clements CB. 2014. FIRETEC evaluation against the FireFlux experiment: preliminary results. VII International Conference on Forest Fire Research D.X. Viegas (Ed.)

Dupuy J-L, Linn RR, Konovalov V, Pimont F, Vega JA, Jimenez E. 2011. Exploring coupled fire/atmosphere interactions downwind of wind-driven surface fires and their influence on backfiring using the HIGRAD-FIRETEC model. International Journal of Wildland Fire, 20, 734750.

Ellis PF. 2000. Review of current methodology of assessment of bushfire hazard and the prescription of appropriate separation distances and building standards. CSIRO Forestry and Forest Products Client Report 901. (Canberra, ACT)

Linn RR, Cunningham P. 2005. Numerical simulations of grass fires using a coupled atmosphere-fire model: basic fire behavior and dependence on wind speed. Journal of Geophysical Research, 110, D13107.

Linn RR, Anderson K, Winterkamp J, Brooks A, Wotton M, Dupuy J-L, Pimont F, Edminster C. 2012. Incorporating field wind data into FIRETEC simulations of the International Crown Fire Modeling Experiment (ICFME): preliminary lessons learned. Canadian Journal of Forest Research 42(5), 879-898.

Pimont F, Dupuy J-L, Linn RR, Dupont S. 2011. Impact of tree canopy structure on wind-flows and fire propagation simulated with FIRETEC. Annals of Forest Sciences, 68(3), 523-530.

Pimont F, Dupuy JL, Linn RR. 2014. A specific large-scale pressure gradient forcing for computation of realistic 3D wind fields over a canopy at stand scale. Submitted.

Rigolot E, de Coligny F, Dreyfus L, Leconte I, Pezzatti B, Vigy O, Pimont F. 2010. FUEL MANAGER: a vegetation assessment and manipulation software for wildfire modeling. Proceedings of the VI International Conference on Forest Fire Research. D. X. Viegas (Ed.).

Taylor SW, Wotton BM, Alexander ME, Dalrymple GN. 2004. Variation in wind and crown fire behaviour in a northern jack pine - black spruce forest. Canadian Journal of Forest Research 34, $1561-1576$. 